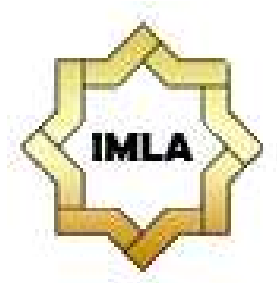

Al-Ta'rib

Jurnal Ilmiah Program Studi Pendidikan Bahasa Arab

IAIN Palangka Raya

Vol. 8, No. 2, December 2020, 229-244

p-ISSN 2354-5887 | e-ISSN 2655-5867

DOI: https://doi.org/10.23971/altarib.v8i2.2257

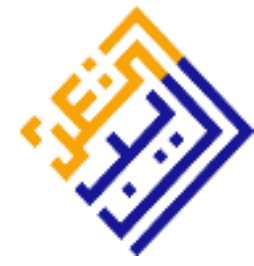

\title{
EFEKTIVITAS PENERAPAN METODE DISCOVERY LEARNING DALAM PEMBELAJARAN IMLA'
}

\author{
Ardyansyah $^{1}$, Laily Fitriani ${ }^{2}$ \\ 1,2Universitas Islam Negeri Maulana Malik Ibrahim Malang, Indonesia \\ E-mail: dyanardy23@gmail.com
}

\begin{abstract}
This study aims at knowing the results of using discovery learning in Imla' and its effectiveness. The research method to be used was quantitative method with experimental design. Data were collected through tests, observation and documentation. The data were analyzed using statistical data analysis $t$ test to determine the level of the effectiveness of discovery learning method. The obtained results illustrated that the discovery learning method in Imla' consists of four stages including exposure, observation and analysis, preparation or formulation of linguistic rules, and application of rules. The application of discovery learning method was very effective in imla' course because it can improve students' understanding of the materials, so that students can write hamzah wasal in the form a word or sentence properly and correctly. This can be seen from the results of the t test carried out in the pre-test and post-test values that the $t$ value was greater than the t table, namely $2.09<21.91>2.86$. Thus, $H_{o}$ is rejected, which means that the method is effective for improving students' writing skill.
\end{abstract}

Keywords: Effectiveness; Discovery Learning Method; Imla' Learning

\section{Abstrak}

Penelitian ini bertujuan untuk mengetahui hasil pembelajaran imla' dengan menggunakan metode discovery learning, serta mengetahui efektivitas penerapan metode tersebut. Metode penelitian yang digunakan adalah eksperimen dengan pendekatan kuantitatif. Pengumpulan data dilakukan melalui tes, observasi, dan dokumentasi. Data tersebut dianalisis dengan menggunakan analisa data statistic uji $t$ untuk mengetahui tingkat keefektifan. Hasil penelitian yang diperoleh menggambarkan bahwa proses pembelajaran imla' dengan penerapan metode discovery learning dalam penelitian ini terdiri dari empat tahap yang meliputi pemaparan, pengamatan dan analisis, penyusunan atau perumusan kaidah kebahasaan, dan penerapan kaidah. Penerapan metode discovery learning sangat efektif dalam pembelajaran imla' karena dapat meningkatkan pemahaman mahasiswa terhadap materi, sehingga mahasiswa dapat menulis hamzah washal dalam bentuk kata ataupun kalimat dengan baik dan benar. Hal ini dapat dilihat dari hasil uji t yang dilakukan terhadap nilai pre-test dan pos-test bahwa nilai $t$ Hitung lebih besar dari t Tabel yaitu 2,09 21,91 >2,86. Dengan demikian, $H_{o}$ ditolak 
yang berarti metode tersebut efektif untuk meningkatkan kemampuan menulis mahasiswa berdasarkan hasil uji coba.

Kata Kunci: Efektivitas; Metode Discovery Learning; Pembelajaran Imla'

\section{Pendahuluan}

Saat ini, kesalahan dalam penulisan huruf Arab umum terjadi di kalangan pelajar lembaga pendidikan Islam yang disebabkan oleh rendahnya keterampilan yang dimiliki (Sebayang et al., 2017), seperti kesalahan dalam penulisan huruf hamzah, huruf mutasyabahah, tanda baca, penyambungan huruf, harkat, dan sebagainya. Menulis merupakan salah satu jenis kecakapan bahasa yang sangat urgen di dalam pembelajaran bahasa Arab dan pembelajaran bahasa asing lainnya. Salah satu jenis pembelajaran dalam keterampilan menulis adalah imla'. Mahmud Ma'ruf (1985) mendefinisikan imla' sebagai kegiatan menulis huruf-huruf menjadi suatu bentuk kata sesuai dengan posisinya yang benar untuk menghindari adanya kesalahan makna kata tersebut (Hermawan, 2018).

Ketika menulis suatu huruf Arab bergandengan dengan huruf Arab lainnya, maka bentuk huruf-huruf Arab tersebut tidak sama, baik ketika terletak di depan, tengah, dan di belakang kata. Oleh karena itu, pembelajaran menulis huruf merupakan pelajaran utama sebagai dasar menuju tahap penulisan berikutnya (Bahruddin, 2017). Sebagai dasar dalam keterampilan menulis, pembelajaran menulis huruf ini tidak hanya dikhususkan untuk tingkatan pertama dalam pembelajaran bahasa Arab, namun pembelajaran menulis huruf (imla') ini juga dipelajari di tingkat menengah dan atas seperti di perguruan tinggi, karena masih dijumpai kesalahan yang dilakukan mahasiswa dalam karya tulis berbahasa Arab. Penulisan huruf yang benar terkadang sulit dilakukan oleh mayoritas orang. Hal ini disebabkan karena pengetahuan mereka yang minim terhadap kaidah penulisan yang baik dan benar.

Institut Agama Islam Negeri Madura adalah Perguruan Tinggi Islam Negeri di Madura yang di dalamnya terdapat Program Studi Pendidikan Bahasa Arab. Penulis memilih mahasiwa semester tiga Prodi PBA sebagai partisipan penelitian, khususnya dalam matakuliah Imla'. Berdasarkan hasil observasi, pembelajaran imla' selama ini sudah dilakukan dengan berbagai macam metode, yaitu ceramah, tanya jawab, simulasi, muraja'ah, guided reading, guided writing dan experiental Learning. Ketika dilakukan latihan menulis dengan teknik imla' ikhtibariy (menulis kata atau kalimat yang didengar tanpa melihat tulisan tersebut sebelumnya), penulis mengamati bahwa beberapa mahasiswa belum mempraktikkan kaidah imla' terutama dalam penulisan hamzah washal. Berdasarkan fenomena tersebut, penulis berkesimpulan bahwa mahasiswa membutuhkan metode yang lebih efektif dan menarik sehingga bisa memotivasi mereka untuk aktif dalam pembelajaran imla', dan mempraktikkannya dalam menulis berdasarkan pada kaidah imla' yang baik dan benar. 
Menurut Kristin, hasil belajar yang meningkat tidak hanya dipengaruhi oleh keinginan belajar mahasiswa, melainkan juga penggunaan metode pembelajaran (Kristin, 2016). Discovery learning merupakan suatu bentuk inovasi baru dalam model pembelajaran bahasa Arab. Model ini memandang mahasiswa sebagai subjek dan objek dalam pembelajaran, yang bisa mengembangkan kecakapan dasar yang dimilikinya dengan sangat baik, sehingga menuntut mahasiswa untuk berperan serta secara aktif dalam proses kegiatan pembelajaran (Mahyudin, 2014).

Dalam metode ini, mahasiswa diajak untuk memahami konsep agar bisa menemukan suatu kesimpulan akhir. Oleh karena itu, mahasiswa akan menyelesaikan suatu masalah baik secara mandiri maupun kelompok di bawah atau tanpa bimbingan dari guru.

Dalam pembelajaran bahasa Arab, pengembangan model discovery learning bisa dilakukan dengan memodifikasinya dari pembelajaran induktif, yaitu berangkat dari suatu kaidah yang khusus menuju ke umum, yang disebut discovery terbimbing (guided discovery). Model ini dimulai dari menjelaskan materi terlebih dahulu, dilanjutkan dengan implementasi kaidah, dan akhirnya secara tegas berpusat pada kaidah kebahasaan dan pelaksanaan dalam penerapannya. Pada model discovery terbimbing, dosen tetap berperan sebagai fasilitator yang mengarahkan pembelajar pada kebenaran untuk menghindari terjadinya kesalahpahaman terkait suatu kaidah kebahasaan, sehingga dengan model ini, kegiatan pembelajaran akan lebih berkesan karena partisipasi aktif pelajar dalam proses penyingkapan atau penemuan (discovery) aturan kebahasaan baru secara mandiri. Selain itu, pembelajaran akan lebih bermakna karena mengikutsertakan secara langsung pemikiran pelajar (Mahyudin, 2014).

Menurut Arianto dkk, dalam penerapan metode discovery learning ini, mahasiswa memang dituntut aktif dan kreatif dalam mencari dan merumuskan ilmu secara individu maupun kelompok (Arianto \& Sari, 2019).

Penelitian terkait dengan aplikasi metode discovery dalam pembelajaran bahasa Arab, pernah dilakukan sebelumnya oleh Utiyani dkk. Hasil penelitiannya menunjukkan bahwa penggunaan discovery learning di dalam pembelajaran materi tarakib berdampak terhadap tingkat pemahaman mahasiswa. Penerapan metode discovery learning terbimbing bisa membuat mahasiswa lebih mudah memahami materi tarakib karena keterlibatan mereka secara langsung dalam proses pembelajaran (Utiyani \& Saefuloh, 2019). Berbagai upaya pembelajaran bahasa telah dilakukan dengan metode discovery learning dan menghasilkan penelitian sebagaimana disebutkan oleh (Astuti, 2015; Nafisa \& Wardono, 2019; Rizkiningrum et al., 2020; Sari, 2014; Triyani et al., 2018; Urhalinah Kurnia et al., 2018). Ada juga penelitian yang dilakukan oleh Yossy Idris dkk. Dalam penelitiannya, selama ini pembelajaran menulis dilaksanakan dengan menggunakan metode konvensional, yang mana dalam metode ini mahasiswa lebih banyak bersikap representatif bukan produktif. Selain itu, penggunaan media 
dalam pembelajaran masih rendah sehingga membuat proses pembelajaran menoton. Metode discovery learning dianggap sebagai metode yang bisa memotivasi mahasiswa berkeinginan dan membangkitkan pengetahuan yang dimilikinya, dengan disertai penggunaan media gambar sebagaimana dalam penelitian (Idris et al., 2014). Oleh karena itu, berdasarkan hal tersebut di atas, mendorong peneliti untuk menerapkan metode discovery learning dalam pembelajaran imla' dalam upaya meningkatkan pemahaman mahasiswa pada penulisan kaidah imla' yang baik dan benar.

Pembelajaran imla' berfungsi untuk memberikan konsep menulis kepada mahasiswa secara cepat dan tepat, serta melatih mereka untuk mampu memahami secara mendalam dan mahir dalam menerapkan teori-teori imla' dalam penulisan huruf Arab dalam kehidupan mereka. Setelah mempelajari kaidah imla' ini, mahasiswa hendaknya bisa membedakan kesalahan penulisan kata, kalimat, atau paragraf, mencari tahu penyebab terjadinya kesalahan tersebut, dan mampu membenarkan kesalahan-kesalahan tersebut. Oleh karena itu, pembelajaran imla' akan membuat pembelajar terhindar dari kesalahan dalam menulis huruf Arab dan memberikan pembelajarnya pengetahuan yang lebih baik dalam menulis, sehingga pembelajar bisa menyampaikan ide dalam bentuk tulisan dengan sempurna (Munjiah, 2018).

Pembelajaran imla' merupakan pelajaran dasar dalam keterampilan menulis, sehingga pendidik harus mendesain pembelajaran ini sebaik mungkin dengan menggunakan metode-metode yang inovatif sehingga materi imla' bisa dipahami dengan baik oleh peserta didik. Penelitian terdahulu yang sudah dilakukan terkait pembelajaran ini dilakukan oleh Abdul Aziz Sebayang dkk, yang mengembangkan pembelajaran melalui 8 tahapan dari 9 sistem model desain pengembangan yang diinstruksikan Dick dan Carey (Sebayang et al., 2017). Penelitian lainnya terkait penggunaan metode dalam pembelajaran imla' dilakukan oleh Augusta Fachrur Akbar dalam skripsinya yang menggunakan model Course Review Horay (CRH) dalam pembelajaran imla' (Fachrur, 2014). Selain itu, penelitian juga dilakukan oleh Rana Nailia dengan judul penelitian yang menfokuskan diri pada pengembangan bahan ajar dari buku utama yang bisa digunakan untuk mengembangkan pembelajaran bahasa Arab sehingga menciptakan pembelajaran yang menyenangkan dan efektif (Nailia, 2017).

Berdasarkan hasil observasi penulis pada bulan September lalu memperoleh data hasil penelitian awal mahasiswa prodi PBA kelas A, bahwa hambatan atau kekurangan yang dialami mahasiswa dalam pembelajaran imla' beraneka ragam. Penulis menemukan kekurangan dalam pembelajaran imla' dalam aspek pengembangan struktur dan kebahasaan. Pada aspek struktur, mahasiswa kesulitan dalam mengembangkan bentuk kata, sedangkan dari aspek kebahasaan, mahasiswa masih lemah dalam menulis huruf dengan tepat, termasuk penulisan tanda baca, ejaan, kalimat, dan konjungsi (Observasi di kelas A pada mata kuliah imla'). Jadi, pembelajaran imla' selama ini masih belum optimal karena adanya kekurangan dalam mengembangkan struktur dan kebahasaan. Data tersebut menunjukkan bahwa mahasiswa masih belum memahami dengan baik dan benar bagaimana penulisan hamzah washal yang tepat sehingga ketika diterapkan metode dikte, penulis menemukan banyak kesalahan dalam tulisan mahasiswa. Oleh karena itu, penulis menerapkan metode Discovery learning 
dengan memilih materi yang diajarkan berupa hamzah washal. Oleh karena itu, penelitian ini bertujuan untuk mengetahui proses pembelajaran imla' pada mahasiswa semester tiga prodi PBA di IAIN Madura, mengetahui proses pembelajaran imla' di kelas tersebut ketika diterapkan metode discovery learning, serta mengetahui hasil dari penerapan metode baru dalam pembelajaran imla' terutama berkaitan dengan penguasaan mahasiswa terhadap materi hamzah

washal.

\section{Discovery Learning}

Discovery Learning adalah suatu model pembelajaran yang membimbing peserta didik terhadap suatu aktivitas yang bisa mengembangkan kecakapan peserta didik melalui penemuan dan penyelidikan terhadap suatu konsep materi pembelajaran, sehingga peserta didik memperoleh pengetahuan dengan hasil temuan mereka sendiri bukan dengan cara menghafal atau mengenali sekumpulan fakta (Susanti et al., 2016). Discovery Learning dianggap sebagai metode pembelajaran yang memusatkan pada perkembangan kompetensi kognitif peserta didik dan bisa memperbaiki kegiatan pembelajaran (Rozhana, 2019; Sumianingrum et al., 2017). Penerapan discovery learning bisa dilakukan dengan mudah, baik digunakan dalam pembelajaran bahasa asing apa pun dan pada berbagai tingkatan, termasuk dalam pembelajaran bahasa Arab. Dalam pelaksanaan pembelajaran dengan menggunakan metode ini, ada empat langkah yang harus dilaksanakan, yang meliputi pemaparan bahasa melalui contoh atau gambar, observasi dan telaah bahasa lewat pertanyaan guru, penyusunan atau penyimpulan kaidah kebahasaan, dan penerapan kaidah dalam latihan yang bertahap sesuai taraf kerumitannya (Mahyudin, 2014). Discovery learning bisa mengubah peserta didik yang pasif menjadi aktif dan berpikir kreatif, sehingga pembelajaran terpusat pada peserta didik (Qodariyah \& Hendriana, 2015).

Discovery learning mempunyai kelebihan yaitu bisa membangkitkan motivasi belajar peserta didik karena keingin tahuan peserta didik yang tinggi, serta tidak menuntut peserta didik untuk menghafal karena pendidik langsung mengaplikasikan konsep dan prinsip dalam praktek sehingga memudahkan peserta didik mengingat materi lebih lama (Prasetyana et al., 2015). Adapun kelebihan penggunaan model guided discovery learning yaitu bisa membuat peserta didik terlibat secara maksimal dalam pembelajaran, membuat peserta didik berpikir kritis secara aktif, meningkatkan kegiatan pembelajaran peserta didik, membuat peserta didik cakap dan cepat dalam mengerjakan soal, dan melatih siswa untuk menerapkan pengetahuan yang diperoleh dalam kehidupannya (Sulistyowati et al., 2012). Di samping kelebihan tersebut, metode discovery learning juga memiliki kelemahan, yaitu tuntutan terhadap peserta didik untuk mempunyai kesiapan dan kematangan mental karena peserta didik harus mempunyai keberanian dan keinginan untuk bisa memahami dengan baik lingkungan di sekitarnya; tidak efektif jika diterapkan untuk kelas dengan peserta didik banyak; sulit menerapkan metode ini karena terbiasa dengan metode lama; dan kritik yang muncul terhadap metode ini karena dianggap hanya memperhatikan proses kognitif saja, tanpa mempedulikan perkembangan afektif dan psikomotorik peserta didik (Hanafiah \& Suhana, 2010). Selain itu, kelemahan 
yang ada dalam metode ini yaitu adanya kemungkinan tidak memberikan peserta didik untuk berpikir kreatif (N. K., 2012).

\section{Pembelajaran Imla'}

Ilmu imla' adalah salah satu cabang dari ilmu bahasa Arab yang mempelajari dasar dalam menulis yang tepat yang bertujuan untuk menghindari kesalahan dalam penulisan huruf. Pembelajaran imla' dianggap sangat penting karena bisa membuat peserta didik mampu menyimak dan menulis apa yang didengarnya dengan benar (Sebayang et al., 2017). Pembelajaran imla' merupakan langkah sistematis yang dilakukan oleh siswa untuk bisa memahami dan menguasai keterampilan menulis tertentu, yang terdiri dari kemampuan untuk menulis kata dengan baik dan benar (Hermanto, 2018). Dikte menempati tempat yang istimewa dalam cabang bahasa, karena merupakan dasar penting untuk menulis. Ilmu Nahwu dan Sharf adalah sarana untuk penulisan yang benar, baik sintaksis maupun derivasi, sementara imla' adalah sarana untuk menulis suatu bentuk huruf dengan benar dan sebagai sarana komunikasi tertulis (Jannah, 2019). Imla' sangat penting dalam pembelajaran bahasa Arab karena materi tersebut bisa membantu seseorang untuk memahami informasi-informasi tertulis dan memudahkannya untuk memberikan informasi secara tertulis kepada orang lain (Wijaya \& Pimada, 2019).

Pembelajaran imla' mengembangkan tiga dasar kemampuan yang meliputi ketelitian dalam mengkaji, mendengar, dan keluwesan tangan dalam menulis. Pada mulanya, imla' mengarahkan peserta didik untuk mengembangkan kecakapan mereka dalam mengamati kata-kata atau kalimat yang tertulis untuk disalin ke dalam buku tulis mereka. setelah tahap ini dikuasai, peserta didik dilatih untuk mampu menyalin apa yang mereka dengar. Latihan ini dilakukan secara berkalikali sehingga peserta didik mempunyai keluwesan dalam menulis. Di samping itu, peserta didik juga dilatih untuk menguasai makna suatu kalimat yang ditulis melalui diskusi atau tanya jawab yang tercakup dalam rangkaian kegiatan menulis (Hermawan, 2018).

\section{Metode}

Jenis penelitian ini merupakan penelitian kuntitatif dengan metode eksperimen. Partisipan dalam penelitian ini adalah mahasiswa semester tiga tahun akademik 2019/2020, pada Prodi Pendidian Bahasa Arab kelas A dengan jumlah mahasiswa 30. Partisipan ini merupakan sampel yang diambil dengan teknik purposive random sampling (Rohani et al., 2015), yaitu mengambil satu kelas secara acak dari dua kelas. Dalam penelitian ini, data dikumpulkan melalui tes, observasi, dan dokumentasi, dengan menggunakan instrument penelitian berupa unjuk kerja, pedoman observasi, dan pedoman dokumentasi. Unjuk kerja digunakan untuk memperoleh informasi terkait peningkatan kemampuan mahasiswa yang dilakukan dengan memberikan beberapa latihan secara individual seputar materi yang dipelajari, yaitu hamzah washal. Unjuk kerja dilakukan sebelum dan sesudah penerapan metode discovery learning. Observasi digunakan untuk mengetahui proses pembelajaran sebelum penerapan metode discovery learning dan setelah penerapan metode tersebut, yang dilakukan terhadap aktivitas mahasiswa selama proses pembelajaran imla' berlangsung, mulai dari pembelajaran yang dilakukan bersama dosen pengampu mata kuliah 
imla' sampai pada saat penulis melaksanakan praktek mengajar di kelas tersebut. Adapun dokumentasi digunakan untuk memperoleh data terkait materi yang akan diajarkan dan hasil kerja siswa dalam pembelajaran imla'.

Penelitian ini menggunakan desain one group pretest posttest (Rohani et al., 2015) yaitu pelaksanaan tes kemampuan awal dan tes kemampuan akhir mahasiswa dalam pembelajaran imla' yang selanjutnya akan menjadi data dalam penelitian ini. Penelitian ini dilaksanakan dengan beberapa prosedur, yaitu memahami latar penelitian dan persiapan diri, memasuki lapangan, berpartisipasi dalam kegiatan pembelajaran dan mengumpulkan data, serta menganalisis data (Moleong, 2017). Untuk memahami latar penelitian ini, peneliti melakukan pengamatan terhadap partisipan dalam penelitian di dalam kelas ketika pembelajaran imla' berlangsung dan memberikan tes kepada mahasiswa sehingga peneliti bisa mengetahui kemampuan mahasiswa secara langsung dalam imla'. Selanjutnya peneliti menentukan suatu metode baru untuk diterapkan dalam pembelajaran imla' dengan tujuan meningkatkan kemampuan mahasiswa dan mengetahui keefektifan penerapan metode tersebut. Peneliti mempersiapkan diri untuk menerapkan metode baru dengan menentukan materi dan berbagai macam latihan. Setelah semua persiapan selesai, peneliti mempraktekkan metode tersebut dalam pembelajaran imla' di kelas yang sudah dilakukan observasi sebelumnya. Untuk menganalisis data yang sudah terkumpul, peneliti menggunakan model analisis data tes " $t$ " yang dilambangkan $t_{o}$, dimana partisipan yang mengikuti tes dalam penelitian ini jumlahnya kecil, dan antara sampel yang satu dengan yang lainnya saling berhubungan, sehingga perhitungannya bisa menggunakan rumus (Sudijono, 2014): $\mathrm{t}_{\mathrm{o}}=\frac{M_{D}}{S E_{M_{D}}}$.

\section{Hasil dan Pembahasan \\ Penerapan Metode Discovery Learning dalam Pembelajaran Imla' pada Materi Hamzah}

Prosedur dalam pembelajaran yang menggunakan model discovery learning meliputi pemberian stimulus, penjelasan masalah, penghimpunan data, penggarapan data, validasi, dan generalisasi (Susmiati, 2020). Laksono menegaskan bahwa metode pembelajaran merupakan cara penyampaian materi pelajaran sebagai upaya untuk memudahkan mahasiswa dalam menjangkau tujuan pembelajaran atau standar kompetensi yang sudah ditetapkan. Untuk mencapai tujuan pembelajaran imla' pada materi hamzah, dosen menggunakan discovery learning. Dalam penerapan metode ini, dosen melakukannya melalui empat tahap.

Pertama, pemaparan atau ekspose bahasa atau materi hamzah washal melalui contoh atau gambaran. Pada tahap ini, dosen menunjukkan kepada mahasiswa daftar kosakata terkait materi yang dipelajari. Dalam kegiatan ini, mahasiswa diarahkan untuk memahami makna dari setiap kata secara bersamasama. Selanjutnya dosen mulai menjelaskan definisi dan posisi hamzah washal dalam suatu kata. Menurut Anilla dkk, selama ini pembelajaran imla' untuk tahap pertama di tingkat rendah dilaksanakan dengan meminta peserta didik untuk menulis kembali kalimat yang ditulis pendidik, sedangkan di tingkat tinggi peserta didik disuruh untuk menuliskan kembali apa yang dibaca oleh pendidik (Hermanda et al., 2020). 
Kedua, pengamatan dan analisis bahasa melalui pertanyaan pemandu. Pada tahap ini, dosen menyuruh mahasiswa untuk menulis teks qira'ah atau kalimat yang mereka dengar dari teks yang dibaca dosen, dimana teks tersebut mengandung kosakata yang diawali hamzah washal. Sehingga dalam kegiatan ini mahasiswa menganalisis posisi hamzah washal dalam suatu kata. Ketika membaca teks, dosen mengulangi tiga kali untuk kalimat yang panjang.

Ketiga, penyusunan atau perumusan kaidah aturan kebahasaan. Pada tahap ini mahasiswa menukar hasil tulisan mereka dengan temannya untuk dikoreksi. Hal ini sesuai dengan salah satu jenis pengoreksian hasil latihan mahasiswa yang dikemukakan oleh Munjiah. Ia menyatakan bahwa model pengoreksian ini melatih mahasiswa untuk cermat, teliti, dan jujur (Munjiah, 2018). Oleh karena itu, dosen menampilkan teks secara utuh di layar. Sehingga mahasiswa bisa memahami dengan baik letak kesalahan mereka dengan mengajukan alasan dari posisi hamzah tersebut dan menyimpulkan dari kaidah penulisan yang baik dan benar dalam kebahasaan. Pada tahap ini juga, dosen mengajukan beberapa pertanyaan kepada mahasiswa terkait pemahaman terhadap teks.

Keempat, penerapan kaidah dalam tugas latihan yang diurut secara bertahap berdasarkan tingkat kesukaran. Dalam hal ini dosen memberikan berbagai variasi latihan yang dikerjakan secara individu terkait materi yang telah dipelajari. Sebagaimana halnya Sund yang menjelaskan bahwa discovery learning merupakan suatu proses mental yang dialami mahasiswa untuk bisa menyesuaikan dan mengolah suatu konsep atau teori. Proses mental tersebut di antaranya pengamatan, pemahaman, pengertian, penggolongan, penafsiran, penjelasan, pengukuran, pembuatan kesimpulan, dan sebagainya (N. K., 2012). Pengerjaan secara individu dimaksudkan supaya pembelajaran yang terpusat pada mahasiswa benar-benar terealisasi dengan baik sehingga bisa diketahui tingkat kemampuan setiap mahasiswa dalam memahami materi hamzah washal ini.

Latihan pertama dalam tugas praktik ini, dilakukan dengan menulis kembali kalimat setelah mengubah bentuk fi'il mudhari' di dalam kalimat tersebut ke dalam bentuk fi'il 'amar, yang diawali hamzah washal. Dalam latihan ini, empat mahasiswa berhasil menjawab pertanyaan dengan baik. Antusias mereka yang tinggi dalam menjawab soal tersebut dapat diamati ketika mereka mengangkat tangan mereka lebih cepat daripada teman mereka yang lain untuk berhasil dalam kompetisi yang diberikan dosen. Latihan kedua dilakukan dengan memerintahkan mahasiswa untuk membuat mashdar dari fi'il madhi yang diawali hamzah washal. Latihan ini melatih mahasiswa untuk berpikir analisis dalam mengubah bentuk suatu kata ke dalam bentuk yang lain. Latihan ketiga dilaksanakan dengan memberikan kosakata di layar untuk dijadikan sebuah kalimat dalam karangan mereka. Latihan ini melatih mahasiswa untuk mengembangkan kosakata menjadi suatu kalimat sempurna dengan tetap memperhatikan penulisan hamzah washal. Latihan keempat dilaksanakan dengan menyajikan kata berwazan fi'il madhi, kemudian memerintahkan mahasiswa memasukkan huruf alif, sin, dan ta'.

Pada pertemuan selanjutnya, dosen melanjutkan pembelajaran imla' pada materi hamzah washal. Untuk memperkuat dan memperdalam pemahaman mahasiswa terhadap materi tersebut, dosen melanjutkan tahap keempat dari metode discovery learning dengan memperbanyak kegiatan mahasiswa dalam mengerjakan latihan-latihan terkait hamzah washal. Terdapat empat jenis latihan 
yang diberikan kepada mahasiswa. Latihan pertama dalam tahap ini yaitu dengan menyajikan sebuah teks qira'ah kepada mahasiswa. Tugas mahasiswa ialah mencermati teks di layar tersebut dan meminta mahasiswa untuk menanyakan kosakata yang tidak diketahui sebagai bekal mereka untuk menerjemahkan teks tersebut sehingga mereka bisa memahami isi teks tersebut dengan baik. Setelah mahasiswa dianggap bisa memahami teks tersebut dengan sempurna, dosen meminta mahasiswa untuk membuat satu soal di selembar kertas terkait teks tersebut. Selang beberapa menit, mahasiswa diminta untuk menyetorkan hasil pertanyaan yang sudah mereka buat untuk nantinya dibagikan kembali secara acak kepada mereka. Dalam hal ini, mahasiswa diminta untuk maju satu per satu secara bergantian, dengan membaca isi pertanyaan yang mereka peroleh dari kertas tersebut dan menjawabnya di depan kelas.

Pada latihan kedua, dosen meminta mahasiswa untuk menyebutkan kata yang diawali oleh hamzah washal di dalam teks qira'ah tersebut dengan menyertai alasan penulisan hamzah washal di dalam kata tersebut. Untuk memotivasi mahasiswa, dosen memberikan rewards kepada mereka yang mampu menyebutkannya. Pemberian rewards ini bertujuan untuk menstimulus kemampuan kompetitif mereka untuk lebih bersemangat dan meningkatkan antusiasme dalam menyelesaikan masalah.

Latihan ketiga dalam pertemuan ini, dilakukan dengan penyajian beberapa kalimat yang di awali hamzah washal. Dalam hal ini, mahasiswa diminta untuk mengemukakan alasan penulisan hamzah washal di dalam kata yang bergaris bawah.

Latihan keempat dalam tatap muka ini dilakukan dengan membuat lima kalimat dengan menggunakan kosakata yang diawali hamzah washal yang mana kosakata tersebut belum disebutkan pada pembelajaran sebelumnya. Hal ini merupakan tantangan tersendiri bagi mahasiswa karena mahasiswa dituntut untuk mencari kosakata di dalam kamus untuk dijadikan sebuah kalimat.

Pemberian berbagai macam latihan kepada mahasiswa ditujukan untuk memperdalam pemahaman mahasiswa terhadap materi yang diajarkan dan mengetahui tingkat penguasaan mahasiswa terhadap materi tersebut. Sebagaimana pendapat Munjiah yang menegaskan bahwa guru harus sesering mungkin memberikan latihan kepada mahasiswa setelah materi selesai diajarkan. Pemberian latihan-latihan dilakukan setelah mahasiswa memahami dengan baik materi yang dipelajari (Munjiah, 2018). Selain itu, dengan adanya berbagai macam latihan ini, mahasiswa akan berusaha untuk memperoleh pengetahuan mereka sendiri terkait hamzah washal dengan menemukan suatu konsep di dalam setiap soal yang diselesaikan, dan menyimpulkannya sehingga tujuan pembelajaran dengan discovery learning pun tercapai dan pembelajaran imla' bisa dikatakan berhasil dan berjalan dengan baik. Hal ini sesuai dengan penelitian yang dilakukan oleh Wahyu dkk bahwa metode discovery learning bisa memperbaiki prestasi belajar, minat, dan motivasi siswa dalam aktivitas pembelajaran, serta bisa memahami materi pembelajaran secara mendalam dan kemampuan komunikasi peserta didik bisa meningkat (Sulfemi \& Yuliana, 2019). Wahyu dkk juga mengungkapkan bahwa model discovery learning bisa meningkatkan kegiatan dan prestasi belajar peserta didik, khusunya dalam materi pembelajaran yang 
memerlukan interpretasi suatu konsep dan kecakapan matematis yang bagus (Istiana et al., 2015).

\section{Efektivitas Penerapan Metode Discovery Learning dalam Pembelajaran ImIa' pada Materi Hamzah}

Latihan dalam pembelajaran imla' dengan menggunakan metode discovery learning ini dipandang mampu menggerakkan dan mengaktifkan mahasiswa, baik fisik maupun mental. Hal ini tercermin pada bentuk latihan yang diberikan kepada mahasiswa, dimana mahasiswa diajak untuk berpikir secara kritis dan analitis. Mahasiswa sangat antusias dalam usaha mereka untuk menyelelesaikan setiap latihan yang diberikan oleh dosen dengan terlebih dahulu memahami konsep yang sudah dipelajari. Selain itu, mahasiswa juga saling mengoreksi hasil kerja mahasiswa yang lain sehingga mereka mengetahui kesalahan mereka dalam menjawab soal. Mahasiswa bersemangat dan aktif mengerjakan latihan-latihan yang diajukan oleh dosen. Selain itu, walaupun pembelajaran imla' ini latihannya dilakukan secara individu, namun pembelajaran ini juga disertai dengan pemberian rewards dan punishment. Dengan demikian, mahasiswa lebih terdorong dan berkompetisi untuk mendapatkan reward dan sebisa mungkin menghindari punishment yang akan diberikan ketika mereka yang tidak dapat menjawab soal dengan baik.

Hal tersebut diperkuat dengan pengerjaan hasil perhitungan tes " $t$ " dimana mahasiswa yang mengikuti tes awal dan tes akhir hanya ada 25 orang dari 30 mahasiswa. Berdasarkan hasil perhitungan diketahui bahwa jumlah selisih variabel pertama (hasil pre-test) dan variabel kedua (hasil pos-test) adalah 500. Selanjutnya dilakukan perhitungan terhadap nilai rata-rata hitung selisih antara skor variabel satu dan dua dan standar kesesatan dari rata-rata selisihnya untuk mengetahui tingkat perkembangan kemampuan siswa dalam pembelajaran imla', sehingga diperoleh hasil perhitungan $t_{\text {o }}$ sebesar 21,906. Untuk bisa menginterpretasi $t_{o}$, terlebih dahulu memperhitungkan nilai degrees of freedom (df) yang diperoleh sebesar 24. Nilai df tersebut selanjutnya dikonsultasikan dengan Tabel Nilai " $\mathrm{t}$ ", baik pada taraf signifikansi $5 \%$ maupun pada taraf signifikansi $1 \%$ untuk mengetahui efektifitas penerapan metode discovery learning dalam pembelajaran imla'. Untuk taraf signifikansi 5\% diperoleh nilai 2,09 dan taraf $1 \%$ diperoleh nilai 2,86, sehingga dapat diketahui bahwasanya nilai $t_{\mathrm{o}}$ lebih besar dari nilai t tabel, dimana perbandingannya dapat ditulis: 2,09 <21,91 > 2,86. Dengan demikian, bisa dikatakan bahwa metode discovery learning yang diterapkan dalam pembelajaran imla' menunjukkan efektivitasnya yang nyata yang berarti metode tersebut bisa meningkatkan kemampuan mahasiswa di IAIN Madura.

Pada hasil akhir, peningkatan kemampuan mahasiswa dalam pembelajaran imla' menggunakan metode discovery learning bisa tercermin dalam hasil kerja mahasiswa dalam menyelesaikan berbagai variasi latihan yang diberikan oleh dosen. Hal ini bisa ditinjau dari pencapaian indikator pembelajaran imla', dimana rata-rata pencapaian setiap indikator tes kemampuan awal dan tes kemampuan akhir meningkat. Peningkatan indikator tertinggi terjadi pada segi struktur dan kebahasaan, yaitu mahasiswa mulai menunjukkan perbaikan dari segi penulisan hamzah washal, ejaan, dan tanda baca. Adapun peningkatan terendah terjadi pada kemampuan mahasiswa dalam mengembangkan suatu kata dimana mahasiswa 
masih kesulitan dalam mengembangkan kalimat dengan menggunakan kata yang diawali hamzah washal. Menurut Junina dkk, penerapan metode discovery learning dalam pembelajaran bisa meningkatkan keterampilan metakognisi peserta didik dan hasil belajar (Junina et al., 2020).

Keberhasilan penerapan metode discovery learning dalam pembelajaran imla' juga didukung oleh perencanaan dan persiapan dosen yang telah disusun dengan baik. Hal ini sesuai dengan pendapat Miatun dkk bahwa dalam penerapan discovery learning, pendidik harus mempersiapkan pembelajaran secara optimal, baik dalam fasilitas pembelajaran, perangkat pembelajaran, dan pengkondisian peserta didik yang dapat mendukung proses pembelajaran sehingga metode tersebut benar-benar memfasilitasi siswa untuk belajar mandiri (Miatun \& Muntazhimah, 2018).

Keefektifan penerapan metode discovery learning dalam pembelajaran sesuai dengan pendapat Mahdi dkk, dimana dalam pembelajaran berbasis discovery learning, pendidik berperan sebagai fasilitator yang membimbing peserta didik untuk aktif dalam belajar dengan memberikan mereka peluang, serta menfokuskan aktivitas belajar peserta didik untuk mencapai tujuan pembelajaran (Mahdi et al., 2019). Dengan demikian, tujuan pembelajaran imla' bisa dicapai dengan metode discovery learning ini. Pembelajaran imla' bertujuan untuk melatih peserta didik supaya bisa menulis huruf dan kata dengan benar dan tangkas, melatih tingkat kefokusan peserta didik, membuat ilmu pengetahuan peserta didik berkembang lewat tulisan, dan melestarikan pengetahuan yang turun dari generasi sebelumnya ke generasi selanjutnya (Rahmi, 2018).

\section{Kesimpulan}

Pembelajaran imla' merupakan pembelajaran dasar dan paling penting dalam keterampilan menulis. Pelaksanaan pembelajaran imla' dengan menggunakan model discovery learning pada mahasiswa kelas A semester tiga IAIN Madura berjalan dengan baik, yang dapat dilihat pada tiga indikator yaitu: a) Menjelaskan penulisan hamzah washal dalam berbagai macam kata; b) Menjelaskan fungsi hamzah washal; c) Membuat kalimat dengan menggunakan kata yang mengandung hamzah washal. Hasil penelitian ini menyimpulkan bahwa penggunaan metode Discovery learning sangat efektif dalam pembelajaran imla' karena dapat meningkatkan kecakapan mahasiswa dalam menulis huruf-huruf dengan baik dan benar, khususnya dalam penulisan hamzah washal. Mahasiswa mampu menjawab berbagai variasi latihan yang diberikan oleh dosen terkait hamzah washal dengan antusias. Latihan-latihan tersebut berupa dikte, membuat kalimat, mengubah kata yang berbentuk fi'il mudhari ke dalam bentuk fi'il 'amar, membuat mashdar dari fi'il madhi, menganalisis penulisan huruf hamzah di dalam suatu kata, dan sebagainya. Latihan-latihan tersebut tercakup dalam empat tahap dari metode discovery learning, yang meliputi penyajian bahasa melalui contoh atau gambaran, observasi dan telaah bahasa melalui pertanyaan guru, penyusunan atau prnyimpulan kaidah kebahasaan, penerapan kaidah dalam tugas latihan yang diurut secara bertahap berdasarkan tingkat kerumitannya. Di samping latihanlatihan yang diberikan kepada mahasiswa, dosen juga memberikan reward dan punishment sehingga hal tersebut membuat pembelajaran lebih kompetitif dan aktif. 
Adapun manfaat yang bisa diperoleh dengan penerapan metode discovery learning dalam pembelajaran imla' oleh dosen yaitu pembelajaran bisa aktif, kritis, dan analitis. Mahasiswa aktif karena semua mahasiswa dituntut untuk dapat menyelesaikan latihan yang diberikan oleh guru. Mahasiswa kritis karena dituntut untuk dapat memperbaiki setiap kesalahan yang dilakukan oleh mahasiswa lain dalam setiap soal. Mahasiswa analitis untuk dapat menyelesaikan soal yang diberikan oleh guru, mahasiswa harus menganalisis suatu kata terlebih dahulu untuk bisa dijadikan suatu kalimat. Peneliti menyarankan bagi peneliti selanjutnya untuk mengkaji model dan metode lain yang bisa diterapkan dalam pembelajaran Imla' guna membantu peningkatan pemahaman mahasiswa, serta bisa mengkaji penerapan metode discovery learning yang dikombinasikan dengan berbagai macam media pembelajaran.

\section{Referensi}

Arianto, M. A., \& Sari, S. Y. (2019). Discovery Learning in Lesson Study. ICOELT, 276, 81-84. https://dx.doi.org/10.2991/icoelt-18.2019.11

Astuti, M. S. (2015). Peningkatan Keterampilan Bertanya dan Hasil Belajar Mahasiswa Kelas 2 SDN Slungkep 03 menggunakan Model Discovery Learning. Scholaria, 5(1), 10-23.

Bahruddin, U. (2017). Rekonstruksi Pengembangan Pendidikan Bahasa Arab. CV Lisan Arabi.

Fachrur, A. (2014). Penerapan Model Pembelajaran Course Review Horay (CRH) Pada Pembelajaran Imla' Bahasa Arab Untuk Meningkatkan Prestasi Mahasiswa Kelas X-12 MAN 1 Magelang Tahun Ajaran 2013/2014 [Skripsi]. Universitas Negeri Semarang.

Hanafiah, \& Suhana, C. (2010). Konsep Strategi Pembelajaran. PT Refika Aditama.

Hermanda, A. F., Thohir, M., \& Khulwani. (2020). Tingkat Kebutuhan Peserta Didik Terhadap Desain Kamus Saku Imla' di MAN 1 Pamekasan. Lisanan Arabiya, 4(1), 31-56. https://doi.org/10.32699/liar.v4i1.1248

Hermanto, B. (2018). Al-Imla' fi Al-Kitabah. Kariman, 6(2), 289-304.

Hermawan, A. (2018). Metodologi Pembelajaran Bahasa Arab. PT Remaja Rosdakarya.

Idris, Y., Thahar, H. E., \& Juita, N. (2014). Peningkatan Keterampilan Menulis Karangan Deskripsi Melalui Metode Discovery Dengan Menggunakan Media Gambar Mahasiswa Prodi Pendidikan Bahasa dan Sastra Indonesia Tahun 2011/2012. Jurnal Bahasa, Sastra Dan Pembelajaran, 2(3), 15-28.

Istiana, G. A., S., A. N. C., \& Sukardjo, J. S. (2015). Penerapan Model Pembelajaran Discovery Learning untuk Meningkatkan Aktivitas dan Prestasi Belajar Pokok Bahasan Larutan Penyangga pada Siswa Kelas XI IPA Semester II SMA Negeri 1 Ngemplak Tahun Pelajaran 2013/2014. Jurnal Pendidikan Kimia (JPK), 4(2), 65-73. 
Jannah, P. N. (2019). Problems of Teachers in The Taeching of Imla' for Students of The Ninth Semester in The Islamic Integrated Secondary School "Imam Syafi'i" East Java. Educan: Jurnal Pendidikan Islam, 3(2), 82-99.

Junina, I., Halim, A., \& Mahidin. (2020). The Effect of Discovery Learning-Based Worksheet on Students' Metacognition Skill and Learning Outcomes. AICMSTE, 1460, 1-6. https://doi.org/doi:10.1088/1742$6596 / 1460 / 1 / 012100$

Kristin, F. (2016). Analisis Model Pembelajaran Discovery Learning dalam Meningkatkan Hasil Belajar Siswa SD. Jurnal Pendidikan Dasar Perkhasa, 2(1), 90-98.

Mahdi, I., Hidayani, I., Mulyawan, \& Ramadhan, H. R. (2019). Metode Discovery Learning dalam Pembelajaran Sejarah Khulafaurrasyidin. Edukasi Islami, 8(1), 143-158. https://doi.org/10.30868/ei.v8i01.357

Mahyudin, E. (2014). Model Discovery Learning sebagai Strategi Pembelajaran Bahasa Arab. Arabiyat, 1(2), 196-208. http://dx.doi.org/10.15408/a.v1i2.1138

Miatun, A., \& Muntazhimah. (2018). The Effect of Discovery Learning and ProblemBased Learning on Middle School Students' Self-Regulated Learning. ICESTEM, 948, 1-7. https://doi.org/doi :10.1088/1742-6596/948/1/012021

Moleong, L. J. (2017). Metodologi Penelitian Kualitatif. PT RemajaRosdakarya.

Munjiah, M. (2018). Kaidah-Kaidah Imla': Teori \& Praktik. UIN Maliki Press.

N. K., R. (2012). Strategi Belajar Mengajar. PT Rineka Cipta.

Nafisa, D., \& Wardono. (2019). Model Pembelajaran Discovery Learning Berbantuan Multimedia untuk Meningkatkan Kemampuan Berpikir Kritis Mahasiswa. Prosiding Seminar Nasional Matematika, 2, 854-861.

Nailia, R. (2017). Pengembangan Bahan Ajar Imla' untuk Keterampilan Menulis Bahasa Arab bagi Mahasiswa Kelas VII MTs. Universitas Negeri Semarang.

Prasetyana, S. D., Sajidan, \& Maridi. (2015). Pengembangan Model Pembelajaran Discovery Learning yang Diintegrasikan dengan Group Invertigation Pada Materi Protista Kelas X SMA Negeri Karangpandan. Jurnal Inkuiri, 4(2), 135148. https://doi.org/10.20961/inkuiri.v4i2.9628

Qodariyah, L., \& Hendriana, H. (2015). Mengembangkan Komunikasi dan Disposisi Matematik Siswa SMP melalui Discovery Learning. Edusentris, 2(3), 241252.

Rahmi, N. (2018). Pengembangan Materi Qawa'id Al Imla' sebagai Penunjang Mata kuliah Kitabah I (Studi pada Mahasiswa Jurusan PBA Fakultas Tarbiyah IAIN Metro). An-Nabighoh, 20(1), 111-128.

Rizkiningrum, M. A., Suri, W. L., \& Erliyani. (2020). Efektifitas Penggunaan Metode DIscovery Learning terhadap Hasil Belajar Menulis Kalimat Bahasa Jepang. Muhammadiyah University Press, 21(2), 148-155. 
Rohani, S., Sutiarso, S., \& Gunowibowo, P. (2015). Efektivitas Model Discovery Learning untuk Meningkatkan Kemampuan Pemecahan Masalah Matematis Siswa. Jurnal Pendidikan Matematika UNILA, 3(3).

Rozhana, K. M. (2019). Lesson Study dengan Metode Discovery Learning dan Problem Based Instruction. Inteligensi, 1(2), 39-45.

Sari, V. N. (2014). Penerapan Model Discovery Learning sebagai Upaya Meningkatkan Kemampuan Menulis Teks Cerita Petualangan Mahasiswa Kelas IV Sekolah Dasar. JPGSD, 2(2), 1-10.

Sebayang, A. A., Nahar, S., \& Mardianto. (2017). Desain Pembelajaran Imla' Dalam Meningkatkan Kemampuan Menulis Tulisan Arab Bagi Santri Di Pondok Pesantren Ar-Raudlatul Hasanah Medan. Edu Religia, 1(4), 573-588. http://dx.doi.org/10.47006/er.v1i4.1089

Sudijono, A. (2014). Pengantar Statistik Pendidikan. PT RajaGrafindo Persada.

Sulfemi, W. B., \& Yuliana, D. (2019). Penerapan Model Pembelajaran Discovery Learning Meningkatkan Motivasi dan Hasil Belajar Pendidikan Kewarganegaraan. Jurnal Rontal Keilmuan PKn, 5(1), 17-30.

Sulistyowati, N., Widodo, A. T., \& Sumarni, W. (2012). Efektivitas Model Pembelajaran Guided Discovery Learning terhadap Kemampuan Pemecahan Masalah Kimia. Chem In Edu, 2(1), 49-55.

Sumianingrum, N. E., Wibawanto, H., \& Haryono. (2017). Efektivitas Metode Discovery Learning Berbantuan E-Learning di SMA Negeri 1 Jepara. IJCET, 6(1), 27-35.

Susanti, E., Jamhari, M., \& Suleman, S. M. (2016). Pengaruh Model Pembelajaran Discovery Learning terhadap Keterampilan Sains dan Hasil Belajar Siswa Kelas VIII tentang IPA SMP Advent Palu. Jurnal Sains Dan Teknologi Tadulako, 5(3), 36-41.

Susmiati, E. (2020). Meningkatkan Motivasi Belajar Bahasa Indonesia melalui Penerapan Model Discovery Learning dan Media Video dalam Kondisi Pandemi Covid-19 bagi Siswa SMPN 2 Gangga. Jurnal Paedagogy, 7(3), 210215. https://doi.org/10.33394/jp.v7i3.2732

Triyani, N., Romdon, S., \& Ismayani, M. (2018). Penerapan Metode Discovery Learning pada Pembelajaran Menulis Teks Anekdot. Parole, 1(5), 713-720. http://dx.doi.org/10.22460/p.v1i5p\%25p.978

Urhalinah Kurnia, D., Silva, P. S., \& Wikanengsih. (2018). Penerapan Metode Discovery Learning pada Pembelajaran Menulis Teks Eksposisi. Parole, 1(6), 1021-1028. http://dx.doi.org/10.22460/p.v1i6p\%25p.1733

Utiyani, \& Saefuloh, H. (2019). Pengaruh Metode Pembelajaran Guided Discovery terhadap Tingkat Pemahaman Mahasiswa pada Materi Tarakib di Madrasah Aliyah Mafatihul Huda Cirebon. El-Ibtikar, 8(1), 119-133. http://dx.doi.org/10.24235/ibtikar.v8i1.4817 
Wijaya, I. S., \& Pimada, L. H. (2019). Ta'lim al-Imla' bi Al-Wasit al-Muta'addidah li Tarqiyyah Maharah al-Kitabah fi al-Lughah al-'Arabiyyah. Al-Bayan, 11(2), 320-339. https://doi.org/10.24042/albayan.v\%vi\%i.5266

\section{Copyright Notice}

Authors retain copyright and grant the journal right of first publication with the work simultaneously licensed under a Creative Commons Attribution 4.0 International License that allows others to share the work with an acknowledgement of the work's authorship and initial publication in this journal.

(c) (1) (2) 


\section{HALAMAN INI SENGAJA DIKOSONGKAN}

